\title{
THE RELEVANCE OF EXCESS CASH TO EXPLAIN FINANCIAL PERFORMANCE AND STOCK RETURNS IN BRAZILIAN LISTED FIRMS
}

\author{
Romário Borges Miranda \\ Renê Coppe Pimentel ${ }^{2}$ \\ Francisco Antonio Bezerra ${ }^{3}$
}

\begin{abstract}
This paper analyzes the determinants and consequences of excess cash (ECM) in relationship to financial performance and stock returns in the Brazilian market which is characterized by concentration in the stock market given that Brazil is an emerging country with high political, economic and institutional uncertainties. This analysis is based on 290 Brazilian non-financial companies listed in the B3 stock exchange from 2000 to 2017. The results suggest that firms with higher excess of cash are those with higher financial performance and higher stock returns which indicates that those firms have higher potential for future growth, therefore firms hold cash for speculative reasons. In pairwise analysis, ECM and firm systemic risk had a negative and significant association, suggesting that excess of cash can also be a potential instrument for risk reduction however overall the results of risk variable do not indicate a consistent role. Analysis of lag structure of ECM indicates a positive association between current ECM and short-term (one-year) returns with stock prices, suggesting that market agents use excess cash to take advantage of investment opportunities. Therefore all evidence suggests that firms retain cash based on the speculative motive.
\end{abstract}

Keywords: Excess cash; Characteristic of the cash; Stock returns.

\footnotetext{
' romariobmiranda@hotmail.com - Faculdade de Ciência e Educação do Caparaó (FACEC)

2 renecp@usp.br - Universidade de São Paulo

${ }^{3}$ francisco@fucape.br - FUCAPE Business School 


\section{A RELEVÂNCIA DO EXCESSO DE CAIXA NA EXPLICAÇÃODO DESEMPENHO FINANCEIRO E DO RETORNO DAS AÇÕES DAS EMPRESAS BRASILEIRAS}

Resumo: Este artigo analisa os determinantes e consequências do excesso de caixa (ECM) em relação a performance financeira e o retorno das ações no mercado brasileiro que é caracterizado pela concentração do mercado acionário, enquanto Brasil é um país emergente com grandes incertezas políticas, econômicas e institucionais. A análise foi baseada em 290 empresas não financeiras brasileiras listadas na bolsa de valores B3 no período de 2000 a 2017. Os resultados sugerem que as empresas com maiores excessos de caixa são aquelas que possuem maiores performance financeira e maiores retorno das ações que indica aquelas firmas com maiores potenciais de crescimento futuro, portanto as empresas detêm caixa por razão especulativa. Na análise pairwise, ECM e o risco sistêmico tiveram uma relação negativa e significante, sugerindo que excesso de caixa pode ser um potencial instrumento para redução do risco, contudo os resultados gerais da variável risco não indicam um papel consistente. As análises do ECM defasados indicam uma relação positiva entre o ECM atual e de curto prazo (um ano) com os preços das ações, sugerindo que os agentes do mercado usam excesso de caixa para tirar vantagens de oportunidades de investimentos. Portanto, todas as evidências sugerem que as empresas retêm caixa baseadas no motivo de especulação.

Palavras-chave: Excesso de caixa. Característica do caixa. Retorno das ações. 


\section{INTRODUCTION}

C ash management (and other financial assets) in firms is a central point in financial literature. On the one hand, the lack of adequate volume of cash resources can be decisive for the insolvency of a company. On the other hand, excess cash may jeopardize the profitability of firms, since cash tends to have lower returns than other operating assets (Steijvers \& Niskanen, 2013).

However, cash management can be very different between companies, even between companies considered similar from the sectoral point of view (Simutin, 2010). For example, Suzano Papel ended fiscal year 2014 with $12.95 \%$ of total assets allocated in cash and cash equivalents, while Fibria Celulose had $1.8 \%$ of total assets in cash and cash equivalents. The reasons for such differences may be diverse: financial strategies for preserving payment capacity, operational decisions to finance working capital, postponement of possible future investments, etc.

Typically, firms maintain cash level and cash equivalents (Henceforth referred to as "cash") to cover their basic operating activities and their investment needs in new projects. However, some firms often maintain a certain level of cash in excess of that necessary to finance operating and investment activities. Such excess cash - described in this paper as "ECM" - Excess Cash Measure - is typically held in the firms for precautionary or speculative motives.

The first reason (precautionary) suggests that companies with lower capacity to raise external financial resources and/or to generate them internally tend to maintain larger amounts of cash. Therefore, these firms become more likely to save a portion of their cash flow when they suffer a financial constraint or perceive an increased risk regarding future cash flow (Opler et al., 1999). Suggesting that managers increase the cash level of firms to avoid the risk of default in the short term, making them safer and less profitable (Bates, Kahle, \& Stulz, 2009).

On the other hand, the speculative motive suggests preferring to retain internal financial resources at lower costs to take advantage of new investment opportunities in risky projects and thus increase their return (Acharya, Davydenko, \& Strebulaev, 2012). In this sense, Simutin (2010) documented that, contrary to intuition, firms with the higher excesses of cash had higher risks, suggesting that the firms hold the level of investment in riskier projects, increasing their total risk.

In the face of conflicting evidence on the subject, this paper aims to analyze the determinants and consequences of excess cash (ECM) on the financial performance and market performance of the shares of companies listed on B3 stock exchange. To analyze such relationships, annual data was collected from 290 listed companies from various economic sectors between 2000 and 2017 (yielding a non-balanced panel of 2,924 firm-year observations). Several estimation approach and analytical tools were used, especially panel data analysis. Additional tests are provided by using alternative measures of variables and approaches, including Fama-MacBeth procedure and analysis of portfolio differences. The ECM is estimated by using the widely and well accepted model proposed by Opler et al. (1999). Specifically, the ECM evidences a discretionary amount, due to its potential to capture unobservable information regarding characteristics that affect the performance of firms (Simutin, 2010).

This paper contributes to the literature by analyzing the excess of cash using a model that aims to identify the optimal amount of cash in the firms, as proposed by Opler et al. (1999). While Martins, Girão and Gartner (2014, p.14), the only paper analysing this issue in Brazil by using a restricted sample of 119 firms, document that "the excess of cash does not show statistically significant relationship with market 
returns", the present research shows the opposite by providing significant evidence of this relationship. Additionally, in the Brazilian market, the remain empirical literature is restricted to analyze the determinants of the effective cash level, in absolute terms, in relation to indebtedness, dividend, immobilization and corporate governance metrics (Tortoli \& Moraes, 2016), in relation to the financial constraints (Costa, Paz \& Funchal, 2008), in relation to transaction costs and the speed of adjustment of the cash balances (Dahrouge \& Saito, 2013) and, finally, in relation to the capital structure of firms (Loncan \& Caldeira, 2014). None of the national studies mentioned, however, specifically evaluated determinants of excess cash and its effects on the financial and market performance of firms.

While international literature documents a positive relationship between excess cash, risks and future stock returns (Simutin, 2010), studies in emerging countries - which have concentrated stock markets, higher political, economic and institutional uncertainties, such as Brazil - are scarce. At the same time, Brazil's macroeconomic scenario of high interest rates can produce a positive relationship, meaning firms can hold cash to anticipate future investment opportunities. In this regard, Section 2.4 provides a broad review of literature and provides key features of Brazilian market that are remarkable to international literature available in developed and emerging countries.

The results of this study have academic and practical implications: on the one hand, it contributes to the literature when analyzing the determinants and consequences of excess cash. On the other hand, it identifies aspects relevant to practically defining policy of management of financial resources and treasury for managers and regulators and their impacts on the stock market return.

In addition to this introduction, this paper contains four more sections: (ii) theoretical framework and hypothesis formulation, (iii) methodology, (iv) results and analysis, and (v) final considerations.

\section{THEORETICAL FRAMEWORK AND HYPOTHESES DEVELOPMENT}

\subsection{Held cash or invest it?}

Managers face a trade-off between investing cash (and liquid assets) or holding it (Assaf Neto \& Silva, 2002). Classical theory indicates that managers hold cash because this makes the firm less risky. This suggests that managers are more concerned with solvency and/or prefer to maintain a certain freedom of choice of resources (discretionary) to maximize shareholder wealth (Bates, Kahle, \& Stulz, 2009; Baumol, 1952). However, since allocating cash for investments suggests increased productivity and on the other hand decreases liquidity, this makes them more risky. A possible increase in profitability and return on shares is also expected with this type of initiative (Acharya, Davydenko, \& Strebulaev, 2012). Thus, managers have to seek a cash balance that satisfies the expectation of risk-return, since they cannot maximize these two aspects at the same time (Assaf Neto \& Silva, 2002).

Regarding the effect of cash on minimizing the risk of default in the short term, Simutin (2010) documents that the risk grows non-significantly in relation to cash. Suggesting a positive relationship between cash and firm risk. This result is in line with the expectation of the classical theory, although firms with more cash have greater capacity for payment and, consequently, are safer.

Therefore, since cash is an endogenous variable, managers could change the cash level in response to current or future events seeking to minimize risk, for example, raise the cash level in response to loss of investment grade and vice versa. Thus, the excess cash does not necessarily imply a reduction of the risk of the firm as a whole (Acharya, Davydenko, \& Strebulaev, 2012; Kim, Mauer, \& Sherman, 1998).

Regarding the main differences between the motives to have cash: precaution or speculation. Firms that hold excess cash for precautionary purposes will use their financial resources less efficiently, because 
they will seek safer and more liquid applications, generating lower returns to the company (Opler et al., 1999).

Meanwhile, companies that hold excess cash for speculation are holding internal financial resources with the assumption that the external resource is expensive in Brazil, to apply them in future investment opportunities, as in Simutin (2010). Suggesting a positive relationship between ECM, risk and future stock returns.

Thus, it can be seen that ECM, a discretionary cash amount, can be used in two different ways and will have different impacts on risk, profitability and future stock returns (Acharya, Davydenko, \& Strebulaev, 2012; Simutin, 2010).

Since the maintenance of high levels of cash imply implies less investments in new profitable projects, there should be a dilemma in the relationship between cash amount held by a firm and its financial performance. As such, managers have to find a balance in the cash accounts. However, at the same time, assuming that firms can hold cash to invest in new projects, those firms that are more able to hold cash can also use cash reserves to take advantage of and invest in high-profit projects when they are available. Thus, it represents a speculative amount of cash to generate high profit returns. In other words, firms with more cash are more able to invest when necessary. Hence, the first empirical hypothesis is:

$\mathrm{H} 1$ : Firms with high ECM have high financial performance.

Unlike the effect of cash on financial performance, the literature agrees that cash maintenances have a negative effect on financial firms. Thus, firms with excess of cash can be seen as less risky. Koshio (2005), for instance, documented in the Brazilian market that firms increase the cash level due to precaution by reducing their risk. This is because cash is one of the safest assets for a firm because cash is less risky than other assets. In this way, it can be expected that firms with higher ECM have lower risks (Acharya, Davydenko, \& Strebulaev, 2012) and the second hypothesis of this study is that:

H2: Firms with high ECM have low systematic risk (low beta).

Based on two first hypothesis, this paper aims to verify whether excess cash is important in explaining firm performance and firm risk in Brazilian non-financial listed firms. Being that excess cash (ECM) is the amount of cash that firms hold above what is necessary to continue operating and investment activities (Asem \& Alam, 2014).

\subsection{Excess cash and stock return}

The assumed relationship between excess cash and stock returns is unclear. The current high cash level may be indicative of future problems, suggesting a negative link between cash and stock returns. On the other hand, firms can accumulate money to use it in future investment opportunities, implying a positive relationship between cash and return (Simutin, 2010; Kim, Mauer, \& Sherman, 1998). This can also be seen from the standpoint of the theory of free cash flows (Jensen, 1986). This theory discusses the possibility that companies with excess cash are exposed to higher agency costs if the excess cash is not distributed or applied to projects of interest to the company.

The classical literature assumes that the increase in the amount of cash in a firm reduces its risk, making it less profitable, which would indicate a negative relationship between cash and expectation of return (Harford, Mansi, \& Maxwell, 2008).

However, Simutin (2010) evidenced that the portfolio return with greater excess cash had an annual return of $5 \%$ above the portfolio return with lower excess cash. In this way, it demonstrated a positive relationship between the excess cash and the future return of the shares. In addition, it has been shown 
that firms with more cash have higher beta, meaning they are more risky. Thus, the evidence found in the US market is consistent in demonstrating excess cash as a proxy for growth option.

Classical finance theory indicates the precautionary motive to minimize the risk of default in the short term. Suggesting a negative relationship between cash and stock returns (Baumol, 1952). On the other hand, the speculative motive suggests that managers should increase the amount of cash to use it in future investment opportunities, indicating a positive relationship between cash and future stock returns (Asem \& Alam, 2014; Simutin, 2010). Forti, Peixoto, and Freitas (2011), which corroborate the speculation in the Brazilian market, showed a positive relationship between cash, operating performance and market value. Thus, the third empirical question is:

H3: Firms with high ECM have high stock returns.

Based on third hypothesis, this paper aims to verify whether excess cash is important in explaining market returns in Brazilian non-financial listed firms.

\subsection{Excess cash and firm characteristics}

Typically, firms have three different reasons for liquidity-preference: (i) the transactions-motive: firms maintain cash to cover their basic operating activities during the intervals between the receipt of income, so firms with higher operating activities costs and longer gaps between receipts of income need to hold higher levels of cash; (ii) the precautionary-motive: firms maintain cash to be prepared for contingencies, therefore firms keep more cash than they need to maintain their activities because of the desire for security and to reduce their risk of default; (iii) the speculative-motive: firms can hold money because they have a better outlook about their future, i.e. a firm can maintain cash because they have a future project which could result in higher interest. Therefore firms can sustain the costs of held cash since they know their future project is profitable enough to cover those costs (Keynes, 1936).

Holding cash brings a cost to a firm, however, getting cash in the short term can be expensive and in some periods there may be great difficulty in obtaining liquidity. Thus, a higher level of cash reduces the risk of default, making them more secure (Bates, Kahle, \& Stulz, 2009; Opler et al., 1999; Baumol, 1952).

Research suggests that companies with higher ECM use the capacity to generate cash as an internal financial resource in investment opportunities. On the other hand, firms show a negative relationship with leverage, working capital, investment in property, plant and equipment and size. Indicating that the companies with high ECM have more guarantees, making them less risky, thereby capturing external resources with lower costs (Steijvers and Niskanen, 2013; Lee \& Powell, 2011; Simutin, 2010, Opler et al., 1999; Kim, Mauer, \& Sherman, 1998). Mikkelson and Patch (2003) document that firms with more excess cash can support large investments and greater asset growth.

As suggested, firms face the trade-off between investing their cash in other assets or holding it. Holding more cash implies lower investments, therefore, lower future cash flows. Meanwhile, less cash increases the risk of insolvency (Acharya, Davydenko, \& Strebulaev, 2012). Bates, Kahle, and Stulz (2009) investigating the relationship between cash generation capacity and excess cash, found a negative relationship. The literature often uses EBITDA as a financial indicator for operating cash generation that varies from company to company depending on the variation of net working capital and expenses on fixed assets, for example. This accounting indicator is preferred by external analysts who evaluate the companies in the stock markets and credit agents to evaluate the operational cash generation (Frezatti \& Aguiar, 2007).

The size of firms can influence cash accumulation. Larger firms have larger amounts of guarantees and are more diversified, so they can obtain financing at lower costs, reducing their need to retain a high amount of cash (Steijvers \& Niskanen, 2013). That is, to identify which amount of cash allows the firm to 
remain solvent and not lose its ability to be profitable (Assaf Neto \& Silva, 2002). However, it can be seen that the increase in the ECM produces lower profitability, thus lowering market value of shareholders' equity. Suggesting a significant relationship between ECM and book-to-market. Large firms have more guarantees and are more diversified. As a result, they are able to raise external resources at lower costs, suggesting a lower need to maintain large excesses of cash (Steijvers \& Niskanen, 2013).

Additionally, firms with restrictions on raising external resources may accumulate more cash to pay their financial obligations, meaning an endogenous response to the possibility of scarce financial assets (Acharya, Davydenko, \& Strebulaev, 2012).

Hence, considering the several aspects documented in the finance literature and described above, this paper considers a series of control variables often used in the literature that are considered as causes or consequences of cash holdings, which include market-to-book ratio (as a proxy for firm-specific growth opportunities), firm size, capital expenditures, net working capital, total debt, EBITDA, sales growth, industry and other macroeconomic variables.

\subsection{Why is cash analysis relevant in Brazil and what do we know so far?}

The Brazilian economic environment is a fruitful field for research in cash holdings and excess cash, since interest and inflation rates are historically high which makes the cost of borrowing money high and the macroeconomic scenario is often highly volatile, uncertain and speculative (Pimentel \& Choudhry, 2014). This specific condition generates an additional challenge for financial mangers given that, maintaining excess cash costs more for firms (i.e. higher opportunity cost) and, at the same time, can provide a higher competitive advantage for firms in terms of higher capacity to face financial crisis (precautionary cash amounts) and/or for timely investment in highly profitable projects (speculative cash amounts).

In other words, due to higher cost of opportunity and higher potential competitive advantages, the discretionary excess cash amount can bring higher relevance for firm-specific cash policies.

In the Brazilian literature, a first group of studies analyse the determinants of cash levels. Tortoli and Moraes (2016) analyse the broad determinants of cash levels and find that dividend payments, level of current assets, corporate governance standards are associated with cash levels. While Arata, Sheng, and Lora (2015) show that the degree of internationalization is a determinant of cash, being cash holding increased as the degree of company internationalization grows.

A second group of studies explicitly analyzes the relation between firm cash levels and firm risk and firm performance. Koshio (2005) documented in the Brazilian market that firms increase the cash level due to precaution by reducing their risk. While Costa, Paz, and Funchal (2008) analyse the effect of demand for liquidity in financial constraints in Brazil and document that financially constrained firms are likely to display higher cash flow sensitivity of cash, while unconstrained firms do not. And Forti, Peixoto, and Freitas (2011) investigate whether nominal cash holdings level affects operational performance of Brazilian firms and show that the financial performance measured and the market value are positively affected by the firms' retention of cash. These studies measure cash at its level (i.e. they do not account for excess of cash).

In this regard, Dahrouge \& Saito, R. (2013) analyze the adjustments of cash to its optimum level using a dynamic model and document that availability of credit, the high cost of bank debt, especially long-term debt, during crisis are determinants of the speed of cash adjustments to its theoretical optimum level. Martins, Girão and Gartner (2014) with a restricted sample of Brazilian firms (119 firms) explicitly accounts for excess cash and its relationship with future performance (proxied by accounting earnings 
at level). However, the study does not document consistent and significant relationship between firm performance and cash.

Considering the current available literature analyzing the Brazilian market, this paper fills a gap in analyzing the effects of excess cash and its implication on firm performance, firm risk and market returns in a comprehensive sample of Brazilian firms with extended controls for firm-specific characteristics, macroeconomic environment and different estimation approaches.

\section{METHODOLOGICAL PROCEDURES \\ 3.1 Collection and processing of data}

The sample is composed of non-financial firms with stocks listed on [B]3 (the Brazilian Stock Exchange) with data available between 2000 and 2017. The data was taken from Economatica's database and the observations collected refer to the last business day of December of each year referring to the consolidated financial statements. The sample considers firms with a minimum of five consecutive years of accounting information and stock liquidity different from zero during the analyzed period. The final sample is composed of 290 firms with a non-balanced panel of 2,924 firm-year observations.

Macroeconomic variables (interest rate, exchange rate, GDP and inflation) were taken from Economatica's database, the Central Bank of Brazil (BACEN) and the Brazilian Institute of Geography and Statistics (IBGE).

Because of the adoption of IFRS in Brazil, cash (and equivalents) data comprises two different accounting accounts: the "Cash and Equivalent" and "Investment in Short-Term Securities" accounts were used between 2000 and 2009 (pre-IFRS period). Between 2010 and 2017 (post-IFRS period), the "Cash and Cash Equivalents" and "Short-term Securities" accounts were used. Year dummies were used in conducting estimations in order to reduce eventual effects of different accounting measurements.

\subsection{Description of variables and empirical model}

3.2.1 Excess cash (ECM)

The Opler et al. (1999) modified model describes how much cash is necessary for a firm to maintain its activities, considering some of its characteristics. Following Oler and Picconi (2014), this paper also includes life cycle related variables especially sales growth, year and industry dummies. In this regression the error demonstrates if the firm is retaining more or less cash after meeting basic cash needs. That is, the residual of the regression, the part not explained by the independent variables, is the excess cash measure (ECM). Thus, the greater the residue, the higher the excess cash will be, on the other hand, negative ECM shows that the firms have a cash deficit. The model is expressed as:

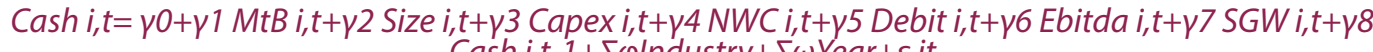
Cash $i, t-1+\sum \varphi$ Industry $+\Sigma \omega$ Year $+\varepsilon$ it

(Eq. 1)

Where:

Cash: Measured by the ratio between cash (and cash equivalents) and net assets, where net assets refers to total assets less cash and cash equivalents, with data from firm i at the end of each year.

MtB: is a relationship between total assets less the book value of equity plus the market value of equity divided by total assets. This variable controls differences between the growth potential of the firms according to market valuation; 
Size: represented by the natural logarithm of the total assets and then divided by 100 ;

Capex: Measured by the ratio between capital expenditures (CAPEX) and total assets;

NWC: net working capital measured as between current assets less cash minus current liabilities scaled (divided) by total assets;

SGW: sales growth measure is the nominal variation in sales from year $\mathrm{t}-1$ to year $\mathrm{t}$ divided by total assets end of each year;

DEBT: measured by the ratio of total debt to total assets, with the data of firm i at the end of each year;

EBTIDA: measured by the ratio between earnings before interest, taxes, depreciation and amortization (EBITDA) available at Economatica to total assets, is a measure of the potential cash generated;

$\varepsilon i$ : Represents the regression residue, thus the ECM of each firm at the end of each year.

In the above equation, we also include the lagged value of CASH (cash in $\mathrm{t}-1$ ) to reduce potential effects of endogeneity in error estimation (Fair, 1970). Additionally, we include industry fixed effects as well as year dummy variables to control for the effect of time-related industry and macroeconomic patterns (Oler \& Picconi, 2014; Xu et al, 2016).

\subsubsection{Characteristics of excess cash}

After finding the excess cash measure (ECM), statistical tests were performed to evaluate the significance of the potential determinants of excess cash.

$E C M i, t=a 0+\beta 1$ FinancialPerformance $i, t+\beta 2$ Beta $i, t+\beta 3 B t M i, t+\beta 4$ Asset Growth $i, t+\beta 5$ Size $i, t+\beta 6$ Exchange Rate $i, t+\beta 7$ Interest Rate $i, t+\beta 8$ GDP $i, t+\beta 9$ Inflation $i, t+\beta 10 E C M i, t-1+\varepsilon i, t$

(Eq.2)

Where:

ECM: was calculated as the error of equation 1 of firm $\mathrm{i}$ in year $\mathrm{t}$;

Financial Performance: is measured in two ways, first based on return on investments (ROIC) and based on return on equity (ROE). $\mathrm{ROIC}$ is the ratio between profit before tax plus net financial expenses divided by average assets, and ROE is the ratio between net profit and average book value of equity;

Beta: calculated using the last 60 months considering the lbovespa Index as the benchmark;

MtB: the ratio between the book value of equity divided by market value of equity;

Asset growth: the ratio of the difference between the total asset in year $\mathrm{t}$ and $\mathrm{t}-1$, then divided by the total asset in $\mathrm{t}-1$;

Size: is the natural logarithm of total asset divided by 100 ;

Exchange rate: is the average of the exchange rate of purchase in Brazil during year $t$ in $R \$ / U S \$ ;$

Interest rate: average real Selic rate during year t;

GDP: represented by the natural logarithm of the Gross Domestic Product of Brazil in year t;

Inflation: is the inflation index in year $t$, the index used was the IPCA.

\subsubsection{Stock returns and excess cash}

Testing the hypothesis about the relationship between excess cash and the return of Brazilian firms, diagonal regressions were used with similar macroeconomic controls presented in Soares e Galdi (2011). Thus, the model is described as:

$$
\begin{gathered}
\text { Return } i, t=a 0+\beta 1 \text { ECMi,t+ } \beta 2 \text { Book-to-Market } i, t+\beta 3 \text { Beta } i, t+\beta 4 \text { Size } i, t+\beta 5 \text { Exchange Rate } \\
i, t+\beta 6 \text { Interest Rate } i, t+\beta 7 \text { GDP }+\beta 8 \text { Inflation } i, t+\varepsilon i, t \text { (Eq.3) }
\end{gathered}
$$

Where: 
Returni,t: is the stock buy and hold return of firm $\mathrm{i}$ in the year $\mathrm{t}, \ln (\mathrm{Pt} / \mathrm{Pt}-1)$ and $\mathrm{Pt}$ is the closing share price adjusted for dividend payments and stock splits. Two accumulation periods were used: The first following most part of the literature, considers civil calendar from January to December of year $t$. The second accumulation period considers annual returns cumulated from April to March aiming to capture any return reaction associated with the announcement of earnings for year $t$

In order to test the hypothesis about the relationship between excess cash and future stock returns of the Brazilian firms, a diagonal regression using the empirical model as follows:

$$
\begin{gathered}
\text { Return } i, t=a 0+\beta 1 \text { ECM } i, t+\beta 2 \text { Book-to-Market } i, t+\beta 3 \text { Beta } i, t+\beta 4 \text { Size i, } t+\beta 5 \text { Exchange Rate } \\
i, t+\beta 6 \text { Interest Rate i, } t+\beta 7 \text { GDP i, } t+\beta 8 \text { Inflation } i, t+\beta 9 \text { ECM } i, t-1+\beta 10 \text { ECM i,t- } 2+\beta 11 \text { ECM } \\
i, t-3+\beta 12 \text { ECM i, } t-4+\varepsilon i, t \text { (Eq.4) }
\end{gathered}
$$

Where ECMi,t-1, ECMi,t-2, ECMi,t-3 and ECMi,t-4, represent the lagged ECM. This regression makes it possible to observe if the ECM is related to future stock returns.

\section{EMPIRICAL RESULTS ANALYSIS}

The analysis of the results is subdivided into two parts, the first one analyzes the relationship of excess cash (ECM) with the measures of risk and financial performance, while the second part analyzes the relationship of excess cash and the stock market return.

\subsection{Excess cash and measures of risk and financial performance of firms}

The first step to analyze the effect of excess cash (ECM) in financial performance and market returns is to estimate the expected cash level and, consequently to estimate the cash in excess. This estimation follows well accepted models of literature presented in Lee and Powell (2011), Opler et al. (1999) and Simutin (2010) as described in Equation 1. The rationale is that accounting for determinants of cash holdings (i.e. current and future growth, size, risk, investment and financing levels and life cycles), it is possible to establish a certain level of "ideal cash" for each firm in a given year.

In this regard, Table 1 presents the coefficients of ECM estimation. Results show positive and significant relationships between the cash and the market-to-book, corroborating with the results of Lee and Powell (2011) and Simutin (2010) in the Australian and American markets, respectively, that firms with greater potential for future growth are those that maintain higher levels of liquid assets (cash and cash equivalents).

Firm size, capital expenses and total debt variables show negative and statistically significant coefficients. The first suggests that bigger firms have more guarantees and can obtain financing with lower costs (Steijvers \& Niskanen, 2013). The second suggests that firms with greater current investment have lower relative cash levels, corroborating the findings of Simutin (2010). The third shows that more indebted firms are those that have greater financial restrictions and, therefore, have smaller relative balances of cash, corroborating the results of Simutin (2010), Lee and Powell (2011) and Costa, Paz and Funchal (2008).

Finally, the positive and significant results in EBITDA suggests that firms with higher expectation of operational cash (and potential cash generation) are those with higher cash levels.

Additionally to the variable of interest, Equation 1 considers the lagged values of cash (CASHt-1) as an instrumental variable to reduce potential effects of endogeneity (Fair, 1970) and industry and year fixed effects to account for effect of time, industry and macroeconomic patterns (Oler and Picconi, 2014; Xu et al, 2016). In general, the empirical model presented explains half of cash variance (see Adjusted R2 of 47.5\%) and the coefficients of ECM estimates displayed in Table 1 are based on Pooled OLS framework. 
However, since ECM is the key variable in this paper, we estimate Equation 1 under several estimation procedures. In the sensitivity analysis topic we explore the differences between them and report that results are overall qualitatively the same under different estimation approach.

Table 1: Longitudinal estimation equation of ECM (Eq. 1)

\begin{tabular}{|c|c|c|c|c|}
\hline Variable & Coef & & Std. Err. & t-value \\
\hline Const. & 0.252 & $* * *$ & 0.064 & 3.9 \\
\hline Market-to-book (MtB) & 0.006 & $* * *$ & 0.001 & 4.8 \\
\hline Firm size (SIZE) & -0.998 & $* * *$ & 0.387 & -2.5 \\
\hline Capital expenditures (CAPEX) & -0.700 & $* * *$ & 0.083 & -8.4 \\
\hline Net working capital (NWX) & 0.019 & & 0.020 & 0.9 \\
\hline Total debt to assets (DEBIT) & -0.039 & * & 0.022 & -1.7 \\
\hline Ebitda & 0.080 & $* * *$ & 0.026 & 3.0 \\
\hline Sales Growth (SGW) & -0.045 & & 0.040 & -1.1 \\
\hline Casht-1 & 0.634 & $* * *$ & 0.013 & 47.1 \\
\hline Industry dummy & YES & & Year dummy & YES \\
\hline Obs. & 2,846 & & Adj R2 & 0.475 \\
\hline$F(42,2803)$ & 62.3 & $* * *$ & Root MSE & 0.343 \\
\hline
\end{tabular}

Source: Research data. Prepared by the authors.

After estimating the values of excess cash for each firm, we analyzed the relationships of the ECM with firm performance and firm risk, in an attempt to identify determinants and consequences of maintaining excess cash resources. Thus, a panel analysis was carried out taking into account the two main variables (financial performance and risk), controlling for firm-specific effects (size, current growth of assets and expected growth - proxied by market-to-book ratio) and for macroeconomic scenario.

Table 2 presents the results of the panel between ECM (dependent variable) and risk, measured by market beta and financial performance, measured by return on investment (ROIC) and return on equity (ROE). For the estimation of the equations, regressions were performed with pooled data, with fixed effects. The presentation of the results in Table 2 followed the most adequate methodology as defined by the Chow and Hausman test (reported at the bottom of the table), since the results suggest the use of fixed effects estimation. Specifically, Hausman test results reject the null hypo $\neg$ thesis that the estimators under fixed and random effect are identical, indicating that fixed effects estimates is consistent. Additionally, Chow's (F-) test for poolability re-jects the joint null hypothesis of equal coefficients at standard significance levels (see the bottom of Table 2 for test results) suggesting the use of fixed effect components. Estimations also consider the diagonal heteroscedasticity corrections proposed by White (1980).

The results show that the excess of cash seems not to be associated with market risk, which suggests that systematic risks of the actions do not generate increase in the firm's amount of cash, which goes against the idea of maintaining cash resources as a precaution (as a tool to reduce stock volatility). Regarding performance, both measures, ROIC and ROE presented a positive and significant coefficients at standard levels ( $1 \%$ to $10 \%)$, suggesting that firms with higher returns to shareholders present higher excess cash.

Table 2: ECM Effects on financial performance (ROIC e ROE) and the risk (beta)

\begin{tabular}{|c|c|c|c|c|c|c|}
\hline & \multicolumn{3}{|c|}{ Performance: ROIC } & \multicolumn{3}{c|}{ Performance: ROE } \\
\hline Variable & \multicolumn{2}{|c|}{ Coefficient } & t-statistic & Coefficient & t-statistic \\
\hline Intercept & 0.255 & & {$[0.66]$} & 0.342 & & {$[0.74]$} \\
\hline Financial Performance (ROIC/ROE) & 0.062 & $* *$ & {$[2.17]$} & 0.035 & $*$ & {$[1.73]$} \\
\hline Beta & 0.012 & & {$[0.65]$} & 0.020 & & {$[0.71]$} \\
\hline Market-to-book & -0.006 & $* * *$ & {$[-8.65]$} & -0.004 & $* * *$ & {$[-3.25]$} \\
\hline
\end{tabular}




\begin{tabular}{|c|c|c|c|c|c|c|}
\hline Asset growth & 0.003 & & {$[0.26]$} & 0.003 & & {$[0.15]$} \\
\hline Size & -1.868 & & {$[-0.75]$} & -2.261 & & {$[-0.78]$} \\
\hline Exchange rate & -0.013 & & {$[-0.53]$} & -0.010 & & {$[-0.33]$} \\
\hline Interest rate & -0.055 & & {$[-0.25]$} & -0.159 & & {$[-0.62]$} \\
\hline GDP Growth & -0.411 & $*$ & {$[-1.83]$} & -0.483 & $*$ & {$[-1.85]$} \\
\hline Inflation rate & -0.196 & & {$[-0.56]$} & -0.131 & & {$[-0.31]$} \\
\hline ECMt-1 & -0.242 & $* *$ & {$[-2.28]$} & -0.253 & $* *$ & {$[-2.49]$} \\
\hline Observations & 2,379 & & & 2,196 & & \\
\hline Adj R2 & 0.104 & & & 0.036 & & \\
\hline F-Statistic & 13.5 & $* * *$ & & 4.9 & $* * *$ & \\
\hline Chow-F test & 5.2 & $* * *$ & & 7.1 & $* * *$ & \\
\hline Hausman test & 35.8 & $* * *$ & & 26.9 & $* * *$ & \\
\hline \multicolumn{7}{|c|}{ Note: ***** Significance of 1\%, 5\% and 10\%, respectively. } \\
\hline \multicolumn{7}{|c|}{ Source: Research data. Prepared by the authors. } \\
\hline
\end{tabular}

The results in Table 2 also allow for the inference that market-to-book and GDP growth, proxing for future firm-specific growth and current economic growth, respectively, are negatively and significantly related to excess cash. Specifically, periods of high GDP growth, firms disbursement are higher in order to realize investment opportunities. The disbursement effect and realization of growth opportunities is higher for firms with higher individual growth expectation (proxied by market-to-book ratio). Thus, managers regulate the amount of excess cash in line with expectations and macroeconomic conditions.

Overall, differently from Martins, Girão and Gartner (2014), the empirical results show that excess cash have a positive and significant relationship with firm performance, confirming the hypothesis 1 of this paper. However, there is no evident that systematic risk (beta coefficient) is significantly related to $\mathrm{ECM}$, at least when the control variables are taking in to consideration.

\subsection{Excess cash and stock return of firms}

The empirical models of Equations 4 and 5 were used to test the hypothesis about the relationship of excess cash and stock returns in Brazilian companies, in which Equation 5, evaluates the relationship based on lagged data. The empirical approach is based on similar model presented in Soares and Galdi (2011).

Following the same procedures as described above, the presentation of the results takes in to account the most appropriate regression estimation methodology as defined by the Chow and Hausman tests (reported in the lower part of the table) for fixed and random effects, and the results indicated the estimation by fixed effects as more efficient. Additionally, estimations consider the diagonal heteroscedasticity corrections proposed by White (1980).

Table 3 presents the results of Equation 4 linking excess of cash and the stock return in Brazilian firms, where the stock returns are estimated during the year-calendar (January to December) and during the financial information reporting (from April of year $t$ to March of $t+1$ ). Annual returns cumulated from April to March aim to capture any return reaction associated with the announcement of earnings for yeart (Pimentel, 2015). Additionally, the models include firm-specific, macroeconomic variables and year dummies to account for firm and macro-level environments.

Results indicate a positive and significant relationship between market returns and ECM with both periods of return accumulation (Jan-Dec and Apr-Mar). Market investors seem to react positively to firms that remains high levels of cash (in excess to the expected).

Additional conclusions can be extracted from coefficients of control variables. For instance, the positive and significant coefficient of financial performance and beta indicates, obviously, that firms with 
higher performance have market returns and that the well diffused positive relationship between risk and returns hold in the sample analyzed.

Table 3: Market returns association with excess of cash -

\begin{tabular}{|c|c|c|c|c|c|c|}
\hline \multirow{3}{*}{$\begin{array}{l}\text { Variable } \\
\text { Intercept }\end{array}$} & \multicolumn{3}{|c|}{$\begin{array}{l}\text { Return Accumulation: } \\
\text { January to December }\end{array}$} & \multicolumn{3}{|c|}{$\begin{array}{l}\text { Return Accumulation: } \\
\text { April to March }\end{array}$} \\
\hline & \multicolumn{2}{|c|}{ Coefficient } & \multirow{2}{*}{$\begin{array}{l}\text { t-stat } \\
{[3.42]} \\
\end{array}$} & \multicolumn{2}{|c|}{ Coefficient } & \multirow{2}{*}{$\begin{array}{l}\text { t-stat } \\
{[4.29]}\end{array}$} \\
\hline & 1.574 & $* * *$ & & 2.147 & $* * *$ & \\
\hline ECM & 0.136 & $* *$ & {$[2.46]$} & 0.151 & $* *$ & {$[2.28]$} \\
\hline Financial performance & 0.409 & $* * *$ & {$[3.36]$} & 0.434 & $* * *$ & [3.99] \\
\hline Beta & 0.119 & $* * *$ & {$[2.83]$} & 0.146 & $* *$ & [2.45] \\
\hline Market-to-book & 0.002 & & {$[0.78]$} & 0.001 & & {$[0.37]$} \\
\hline Asset Growth & 0.051 & & {$[1.43]$} & 0.020 & & [1.24] \\
\hline Firm size & -9.035 & $* * *$ & {$[-3.51]$} & -12.877 & $* * *$ & {$[-4.58]$} \\
\hline Exchange rate & 0.733 & $* * *$ & [3.84] & 0.556 & $* * *$ & [3.39] \\
\hline Real interest rate & 7.718 & $* * *$ & [6.12] & 5.474 & *** & [3.98] \\
\hline GDP growth & -10.646 & $* * *$ & {$[-7.91]$} & -12.384 & $* * *$ & {$[-9.33]$} \\
\hline Inflation rate & -13.914 & $* * *$ & {$[-9.03]$} & -11.717 & $* * *$ & {$[-7.87]$} \\
\hline Year Dummy & YES & & & YES & & \\
\hline Observations & 2,623 & & & 2,633 & & \\
\hline Adj R2 & 0.274 & & & 0.209 & & \\
\hline F-Statistic & 32.5 & $* * *$ & & 33.8 & $* * *$ & \\
\hline Chow-F test & 1.6 & $* * *$ & & 1.9 & $* * *$ & \\
\hline Hausman test & 68.1 & $* * *$ & & 50.9 & $* * *$ & \\
\hline
\end{tabular}

Although the results displayed in Table 3 takes into account macroeconomic elements that may influence stock returns (and they actually do, as reported), and additional test was conduct by using Fama-MacBeth procedure with qualitative equal results for ECM (i.e. positive coefficient statistically significant at standards levels) and the results are available from author under request. In this process, the year specific macroeconomic variables are omitted and estimations are based on year-specific. Specifically, the Fama-MacBeth procedure consists of consecutive cross-section (two-steps approach) regressions. This approach is in line with the formation of portfolios and, consequently, with the categorization in rankings, and additionally provides correction of the standard errors for cross-section correlations.

For purposes of analyzing the behavior among the variables over time, that is, to verify if the absence of a significant relation is not because of the "timing" of the recognition, regressions were made with excess cash in terms lagged between one and five Periods. Thus, Table 4 demonstrates the behavior between the ECM and the future (one to four-year-ahead) stock return.

Results in Table 4 show that market agents recognize to ECM in the current and short-term (one-year) ahead returns. This result corroborates Simutin (2010) by suggesting that firms with excess cash use these resources in investment opportunities. Thus, firms retain cash based on the speculative motive, and therefore, produce greater current and future (short-term) returns. This conclusion is restricted to short-term period, since in longer periods (after two years) the effect of market is non-existent.

Table 4: Lagged structure of market returns association with excess of cash

\begin{tabular}{|c|c|c|c|c|c|c|c|c|c|c|c|c|c|c|c|c|}
\hline \multirow[b]{3}{*}{ Intercept } & \multicolumn{8}{|c|}{ Return Accumulation: January to December } & \multicolumn{8}{|c|}{ Return Accumulation: January to December } \\
\hline & \multicolumn{8}{|c|}{ Coefficients } & \multicolumn{8}{|c|}{ Coefficients } \\
\hline & 2.275 & $* * *$ & 2.415 & *** & 3.243 & $* * *$ & 3.321 & $* * *$ & 2.256 & $* * *$ & 2.321 & *** & 2.709 & $* * *$ & 2.954 & *** \\
\hline & [5.17] & & [4.82] & & [5.59] & & [5.30] & & [5.38] & & [4.85] & & [4.91] & & {$[4.86]$} & \\
\hline
\end{tabular}




\begin{tabular}{|c|c|c|c|c|c|c|c|c|c|c|c|c|c|c|c|c|}
\hline ECM & 0.181 & $* * *$ & 0.032 & & 0.008 & & 0.028 & & 0.185 & *** & 0.096 & & 0.109 & & 0.136 & \\
\hline & [2.60] & & {$[0.32]$} & & {$[0.08]$} & & {$[0.23]$} & & [2.71] & & {$[0.99]$} & & {$[1.06]$} & & [1.15] & \\
\hline \multirow[t]{2}{*}{ ROIC } & 0.385 & $* * *$ & 0.590 & *** & 0.502 & $* * *$ & 0.479 & $* * *$ & 0.341 & $* * *$ & 0.569 & $* * *$ & 0.504 & $* * *$ & 0.441 & $* * *$ \\
\hline & [6.23] & & [6.55] & & [4.81] & & {$[4.30]$} & & {$[5.77]$} & & [6.53] & & {$[5.07]$} & & [4.09] & \\
\hline \multirow[t]{2}{*}{ Beta } & 0.088 & ** & 0.120 & *** & 0.138 & $* * *$ & 0.187 & $* * *$ & 0.129 & $* * *$ & 0.160 & $* * *$ & 0.168 & *** & 0.240 & *** \\
\hline & [2.45] & & [2.99] & & {$[3.01]$} & & {$[3.61]$} & & {$[3.78]$} & & [4.16] & & {$[3.84]$} & & [4.81] & \\
\hline \multirow[t]{2}{*}{ Market-to-Book } & 0.004 & & 0.001 & & 0.003 & & 0.004 & & 0.002 & & 0.001 & & 0.002 & & 0.002 & \\
\hline & {$[1.55]$} & & {$[0.57]$} & & {$[1.38]$} & & {$[1.48]$} & & {$[0.93]$} & & [0.54] & & {$[0.65]$} & & {$[0.73]$} & \\
\hline \multirow[t]{2}{*}{ Asset Growth } & 0.107 & $* * *$ & 0.117 & *** & 0.230 & $* * *$ & 0.225 & $* * *$ & 0.038 & & 0.066 & $* * *$ & 0.149 & $* * *$ & 0.150 & *** \\
\hline & {$[4.21]$} & & {$[4.34]$} & & [4.55] & & {$[4.21]$} & & {$[1.56]$} & & [2.58] & & {$[3.09]$} & & {$[2.90]$} & \\
\hline \multirow[t]{2}{*}{ Size } & -14.646 & $* * *$ & -14.374 & *** & -18.580 & *** & -18.244 & $* * *$ & -15.434 & $* * *$ & -15.349 & $* * *$ & -17.368 & *** & -18.608 & *** \\
\hline & {$[-5.29]$} & & {$[-4.55]$} & & {$[-5.12]$} & & {$[-4.65]$} & & {$[-5.85]$} & & {$[-5.09]$} & & {$[-5.02]$} & & {$[-4.89]$} & \\
\hline \multirow[t]{2}{*}{ Exchange Rate } & -1.447 & $* * *$ & -1.367 & *** & -1.166 & $* * *$ & -0.994 & $* * *$ & -1.337 & $* * *$ & -1.244 & $* * *$ & -1.112 & *** & -1.052 & *** \\
\hline & {$[-18.65]$} & & {$[-16.75]$} & & {$[-13.51]$} & & {$[-10.85]$} & & {$[-18.07]$} & & {$[-16.01]$} & & {$[-13.52]$} & & [-11.85] & \\
\hline \multirow[t]{2}{*}{ Interest Rate } & -1.077 & ** & -1.210 & $* *$ & -2.196 & ** & -2.482 & $* * *$ & 0.103 & & 0.294 & & -0.046 & & -0.209 & \\
\hline & {$[-2.24]$} & & {$[-2.40]$} & & {$[-3.76]$} & & {$[-4.03]$} & & {$[0.22]$} & & {$[0.61]$} & & {$[-0.08]$} & & {$[-0.35]$} & \\
\hline \multirow[t]{2}{*}{ GDP growth } & -1.624 & $* * *$ & -2.040 & *** & -2.695 & $* * *$ & -3.455 & $* * *$ & -2.847 & $* * *$ & -3.096 & $* * *$ & -3.339 & $* * *$ & -3.752 & *** \\
\hline & {$[-3.90]$} & & {$[-4.75]$} & & {$[-5.66]$} & & {$[-6.58]$} & & {$[-7.18]$} & & {$[-7.57]$} & & {$[-7.37]$} & & {$[-7.38]$} & \\
\hline \multirow[t]{2}{*}{ Inflation rate } & 0.322 & & -2.627 & *** & -5.261 & *** & -7.219 & *** & 1.811 & *** & 0.159 & & -1.053 & & -1.937 & ** \\
\hline & {$[0.48]$} & & {$[-3.63]$} & & {$[-6.13]$} & & {$[-7.48]$} & & {$[2.83]$} & & {$[0.23]$} & & {$[-1.29]$} & & {$[-2.07]$} & \\
\hline \multirow[t]{2}{*}{ ECMt-1 } & 0.050 & & 0.195 & **** & 0.226 & $* *$ & 0.355 & $* * *$ & 0.050 & & 0.161 & ** & 0.150 & * & 0.249 & ** \\
\hline & {$[1.15]$} & & [2.83] & & [2.42] & & {$[3.27]$} & & {$[1.19]$} & & {$[2.47]$} & & {$[1.68]$} & & {$[2.37]$} & \\
\hline \multirow[t]{2}{*}{ ECMt-2 } & & & 0.018 & & 0.052 & & -0.103 & & & & -0.022 & & 0.017 & & -0.065 & \\
\hline & & & {$[0.40]$} & & {$[0.73]$} & & {$[-1.06]$} & & & & {$[-0.53]$} & & {$[0.25]$} & & {$[-0.70]$} & \\
\hline \multirow[t]{2}{*}{ ECMt-3 } & & & & & -0.014 & & 0.136 & & & & & & -0.029 & & 0.078 & \\
\hline & & & & & {$[-0.30]$} & & {$[1.85]$} & & & & & & {$[-0.67]$} & & {$[1.09]$} & \\
\hline \multirow[t]{2}{*}{ ECMt-4 } & & & & & & & 0.059 & & & & & & & & 0.017 & \\
\hline & & & & & & & {$[1.24]$} & & & & & & & & {$[0.37]$} & \\
\hline Observations & 2,379 & & 2,069 & & 1,805 & & 1,567 & & 2,363 & & 2,064 & & 1,802 & & 1,565 & \\
\hline F-Statistic & 74.96 & $* * *$ & 68.33 & *** & 50.96 & $* * *$ & 43.8 & $* * *$ & 75.95 & $* * *$ & 65.54 & $* * *$ & 44.55 & $* * *$ & 38.41 & *** \\
\hline Adj R2 & 0.1428 & & 0.1721 & & 0.1067 & & 0.1013 & & 0.1244 & & 0.1348 & & 0.0852 & & 0.0709 & \\
\hline
\end{tabular}

Overall, results in this paper document a positive and significant association between excess cash and market returns. It means the firms that held higher levels of cash (in excess) are those that outperform firms with low levels of cash. This result does not confirm the idea of cash trade-off, as suggested by the classic literature and differs from Martins, Girão and Gartner (2014) who do not find significant relationship between the variables in the Brazilian Market. However, it indicates that firms with excess cash are those with higher capacity to investment in profitable projects and market agents are willing to pay additional price to that. Hence, the evidence suggests that firms keep high levels of cash to invest

when the scenario is positive what is explained by the speculative reason to held excess of cash.

\subsection{Sensitivity analysis and extensions}

All the empirical models tested above, takes into account (correctly) the joint effect of ECM in market risk (beta), firm performance (ROIC and ROE) and controlled variables. In order to further analyze de individual effect of ECM in these and control variables, this paper develops as a complementary analysis a portfolio and correlation analysis.

Table 5 displays sample segregation into four and three portfolios accounting to level of ECM from low to high ECM observations and, in the last column, the spearman non-parametric correlation coeffi- 
cients. Overall, the coefficients are consistent with those reported previously, especially in those related to financial performance (ROIC and ROE) and market performance (returns accumulated from January to December and from April to March). However, when only pairwise relations are analyzed (i.e. not in a joint model as estimated previously in this paper), more variables seem to be related to ECM, especially market risk. In this pairwise approach, ECM varies negatively to beta, suggesting that firms with higher levels of excess cash are those with less market risk (i.e. less systematic risk exposition).

Interpretation other variables analyzed in this paper, a possible way to interpret the results, in a pairwise framework, is that firms with higher growth potential (market-to-book ratio) are those that maintain more cash. This is especially true for large firms (proxied by logarithm of total assets), that higher levels of long-term investments (proxied by Capex) and that have higher access to debit market (proxied by total debt).

The positive relation between ECM and financial performance does not confirm the idea of cash trade-off, as suggested by the classic literature. On the other hand, the significant relations between ECM and Capex, market to book ratio and asset growth show that the positive effect of financial and market performances may be derived from higher levels of investments in profitable projects, suggesting that firms keep higher levels of cash to invest, when the scenario is positive (i.e. the speculative reason to held excess of cash).

Finally, the positive relation with total debt and the non-significant relation with Ebitda suggest that excess cash may be an exogenous response of managers to the possibility of insufficient resources from operations to attend the investment expectation (Acharya, Davydenko, \& Strebulaev, 2012).

Table 5: Portfolio analysis according to ECM level

\begin{tabular}{|c|c|c|c|c|c|c|c|c|c|c|c|c|c|}
\hline \multirow{3}{*}{$\begin{array}{l}\text { Variables } \\
\text { N (2846) }\end{array}$} & \multicolumn{6}{|c|}{ Four Portfolios Averages } & \multicolumn{5}{|c|}{ Three Portfolios Averages } & & \\
\hline & \multirow{2}{*}{$\begin{array}{l}\text { Low } \\
\text { ECM } \\
712\end{array}$} & \multirow{2}{*}{$\begin{array}{c}\text { Med. } \\
\text { /Low }\end{array}$} & \multirow{2}{*}{$\begin{array}{c}\begin{array}{c}\text { Med./ } \\
\text { High }\end{array} \\
712\end{array}$} & \multirow{2}{*}{$\begin{array}{c}\text { High } \\
\text { ECM }\end{array}$} & \multicolumn{2}{|c|}{$\underset{\text { (t-test) }}{\text { High-Low }}$} & \multirow{2}{*}{$\begin{array}{l}\text { Low } \\
\text { ECM } \\
949\end{array}$} & \multirow{2}{*}{$\begin{array}{c}\begin{array}{c}\text { Medium } \\
\text { ECM }\end{array} \\
949\end{array}$} & \multirow{2}{*}{$\begin{array}{c}\begin{array}{c}\text { High } \\
\text { ECM }\end{array} \\
948\end{array}$} & \multicolumn{2}{|c|}{$\begin{array}{c}\text { High-Low } \\
\text { (t-test) }\end{array}$} & \multicolumn{2}{|c|}{$\begin{array}{l}\text { Spearman Correl. } \\
\text { Coefficient }\end{array}$} \\
\hline & & & & & & & & & & & & & \\
\hline ECM & -0.171 & -0.049 & 0.003 & 0.217 & {$[-16.7]$} & $* * *$ & -0.145 & -0.023 & 0.168 & {$[-17.7]$} & $* * *$ & & \\
\hline Cash & 0.100 & 0.096 & 0.139 & 0.466 & {$[-11.1]$} & $* * *$ & 0.097 & 0.115 & 0.388 & {$[-11.5]$} & $* * *$ & 0.543 & $* * *$ \\
\hline Beta & 0.304 & 0.255 & 0.225 & 0.248 & {$[2.4]$} & $* *$ & 0.300 & 0.226 & 0.248 & {$[2.3]$} & $* *$ & -0.067 & $* * *$ \\
\hline Stock return (Jan-Dec) & 0.016 & 0.017 & 0.058 & 0.118 & {$[-3.0]$} & $* * *$ & 0.025 & 0.024 & 0.108 & {$[-2.9]$} & $* * *$ & 0.068 & $* * *$ \\
\hline Stock return (Apr-Mar) & -0.003 & 0.038 & 0.076 & 0.115 & {$[-3.6]$} & $* * *$ & 0.016 & 0.047 & 0.106 & {$[-3.2]$} & $* * *$ & 0.096 & $* * *$ \\
\hline ROE & 0.060 & 0.059 & 0.068 & 0.074 & {$[-2.5]$} & $* *$ & 0.065 & 0.064 & 0.117 & {$[-2.9]$} & $* * *$ & 0.080 & $* * *$ \\
\hline ROIC & 0.059 & 0.062 & 0.088 & 0.119 & {$[-0.5]$} & & 0.060 & 0.064 & 0.072 & {$[-0.6]$} & & 0.084 & $* * *$ \\
\hline Debit & 0.235 & 0.282 & 0.326 & 0.322 & {$[-4.3]$} & $* * *$ & 0.243 & 0.310 & 0.321 & {$[-5.0]$} & $* * *$ & 0.144 & $* * *$ \\
\hline Market-to-book & 3.103 & 1.499 & 1.773 & 2.267 & {$[2.0]$} & $* *$ & 2.678 & 1.619 & 2.185 & [1.6] & & 0.062 & $* * *$ \\
\hline Firm size & 0.135 & 0.146 & 0.152 & 0.147 & {$[-10.9]$} & $* * *$ & 0.138 & 0.150 & 0.148 & {$[-11.6]$} & $* * *$ & 0.202 & $* * *$ \\
\hline Asse growth & 0.112 & 0.089 & 0.118 & 0.781 & {$[-1.6]$} & & 0.097 & 0.102 & 0.625 & {$[-1.7]$} & $*$ & 0.192 & $* * *$ \\
\hline Capex & 0.038 & 0.051 & 0.060 & 0.080 & {$[-7.8]$} & $* * *$ & 0.040 & 0.054 & 0.078 & {$[-8.6]$} & $* * *$ & 0.145 & $* * *$ \\
\hline NWC & -0.049 & -0.010 & -0.018 & -0.022 & {$[-1.2]$} & & -0.039 & -0.017 & -0.019 & {$[-1.1]$} & & -0.071 & $* * *$ \\
\hline Ebitda & 0.069 & 0.091 & 0.096 & 0.062 & {$[0.3]$} & & 0.075 & 0.094 & 0.069 & {$[0.4]$} & & 0.016 & \\
\hline
\end{tabular}

A second sensitivity analysis in this paper tries to analyze alternative estimation procedures. Table 6 show the descriptive of ECM (used to display the previous tables) and other estimation alternatives and a correlation analysis between the estimated ECMs. First, ecmdivid takes in to account the dividend paid by a firm um year $t$, we initially did not include the dummy variables of dividend (for dividend payment or not) because in Brazil, almost the totality of firms have a minimum dividend policies due to legal enforcement. So, a dummy variable would be strongly related to positive earnings itself, including divi- 
dend payments does not change significantly the ERM used in this paper (spearman correlation of 0.999 between the two estimations). Second, in Equation 1, following the existing literature, we included year and industry dummies. However, industry dummies are not strongly consistent with firm fixed effects. Thus, we estimate Equation 1 with firm fixed effects rather than industry dummies and the estimation is named ecmfe. We also did the same by including dividend payments considerations, ecmfedividend. Estimations were conducted with robust White's (1980) diagonal heteroscedasticity corrections. Results are also consistent between the estimations with spearman correlation of 0.893 between the two fixed effects estimated and the displayed previously. Additionally, we used winsorization of variables in Equation 1 at top and bottom $1 \%$. In this case, results are different from the displayed since to top and bottom observations were changed for the $1 \%$ and $99 \%$ values, however, we also document the tendency of positive association with firm and market performances with winsorized ECM. Hence, the overall results are not changed and additional results can be obtained from the author under request.

Table 5: Portfolio analysis according to ECM level

\begin{tabular}{|c|c|c|c|c|c|c|}
\hline \multicolumn{7}{|c|}{ Panel A - Error Descriptives } \\
\hline & ecm & ecmdivid & Ecmfe & ecmfedividend & wecmfe & ecmlc \\
\hline Low & -5.444 & -5.405 & -2.695 & -2.696 & -1.361 & -5.241 \\
\hline $5 \%$ & -0.174 & -0.174 & -0.183 & -0.183 & -0.165 & -0.199 \\
\hline $25 \%$ & -0.079 & -0.079 & -0.116 & -0.116 & -0.083 & -0.078 \\
\hline Med. & -0.024 & -0.022 & -0.061 & -0.061 & -0.026 & -0.018 \\
\hline $75 \%$ & 0.033 & 0.034 & 0.023 & 0.023 & 0.037 & 0.043 \\
\hline $95 \%$ & 0.214 & 0.215 & 0.286 & 0.286 & 0.226 & 0.195 \\
\hline High & 8.382 & 8.392 & 9.505 & 9.505 & 2.549 & 8.393 \\
\hline Meam & 0.000 & 0.000 & 0.000 & 0.000 & 0.000 & 0.000 \\
\hline Stand. Dev. & 0.340 & 0.340 & 0.381 & 0.381 & 0.192 & 0.368 \\
\hline \multicolumn{7}{|c|}{ Panel B - Correlation Matrix } \\
\hline & $\mathrm{ecm}$ & ecmdivid & ecmferobust & ecmfedividend & wecmfe & ecmlf \\
\hline ecm & & $0.989^{* * *}$ & $0.711^{* * *}$ & $0.711^{* * *}$ & $0.844^{* * *}$ & $0.992^{* * *}$ \\
\hline ecmdivid & $0.999 * * *$ & & $0.695^{* * *}$ & $0.695^{* * *}$ & $0.832^{* * *}$ & $0.992^{* * *}$ \\
\hline ecmfe & $0.893^{* * *}$ & $0.893^{* * *}$ & & $1.000^{* * *}$ & $0.763^{* * *}$ & $0.889^{* * *}$ \\
\hline ecmfedividend & $0.893^{* * *}$ & $0.893^{* * *}$ & $1.000^{* * *}$ & & $0.763^{* * *}$ & $0.659^{* * *}$ \\
\hline wecmfe & $0.712^{* * *}$ & $0.711^{* * *}$ & $0.759^{* * *}$ & $0.759 * * *$ & & $0.674^{* * *}$ \\
\hline ecmlc & $0.887^{* * *}$ & $0.894^{* * *}$ & $0.602^{* * *}$ & $0.602^{* * *}$ & $0.742^{* * * *}$ & \\
\hline
\end{tabular}

Finally, this paper analyze the role of business cycle in ECM estimation. Specifically, we follow Oler and Picconi (2014) in include life cycle-related variables in Equation 1. However, we also go further in include dummy variables to account for live cycle stages based on Dickinson's (2011) definition and approach, by using cash flows information. Specifically, we include a dummy variable for firms in "birth and growth" stages and a second dummy for $m$ and shake-out" stages, consequently, the last group is formed by firms in "decline" stage. The ECM estimation controlled by firm life cycle is described in Table 6 as ecmlc and, since cash flow information is available only after 2008, the number of observations is severely reduced (from 2846 to 2082) when compared to previous estimations.

The descriptive statistics and correlations of ecmlc follows the previous estimation. However, tests of Equations 2 (for ROIC and ROE) have their results changed duet to significance loss in financial performance and explanation of cash holdings. Equation 3, on the other hand, yield the same results, suggesting a positive and significant relationship between ECM and market returns (for both accumulation periods). 


\section{FINAL CONSIDERATIONS}

This paper sought to evaluate the relationship that exists between excess cash, financial performance and the stock returns of Brazilian listed firm. As expected, the results suggest that firms with larger absolute amounts of cash (and equivalents) are those with the highest excess cash volumes (ECM).

Overall, different from previous empirical finds, results in this paper document a positive, significant and consistent association between excess cash and firm performance (ROIC and ROE) and market returns. It means the firms that held higher levels of cash (in excess) are those that outperform firms with low levels of cash in financial and market terms. Thus, this result does not confirm the idea of cash trade-off, as suggested by the classic literature. However, it does indicate that firms with excess cash are those with higher capacity to investment in profitable projects and market agents are willing to pay an additional price for that. Additional evidence of this conclusion is that firms with higher levels of excess cash are those with higher potential future growth (proxied by market-to-book ratio). Firms with higher excess cash can support higher investments and asset growth (Mikkelson \& Partch, 2003). Therefore, the results in this paper suggest that firms keep high levels of cash to invest when the scenario is positive which is explained by the speculative reason to hold excess of cash.

Despite the fact that cash resources are safer than other assets, the results do not indicate a consistent role of ECM in firm systematic risk (proxied by beta coefficient) when the relation is controlled by other variables. However, in pairwise analysis (i.e. individual association between the two variables), it is possible to document a negative and significant association between systematic risk and ECM, suggesting that excess of cash can also be a potential instrument for risk reduction (although this association is not consistent under different research approaches). A potential explanation for these results, when combined with firm performance and market performance results is that more profitable firms are less subject to financial constraints and, consequently, can keep additional cash resources to invest in new future projects (Costa, Paz \& Funchal, 2008).

Overall, hypotheses 1 and 3 in this paper are confirmed suggesting a strong positive association between financial and market performances while hypothesis 2, relating systematic risk and ECM, is subject to the kind of analysis conducted. Additional results also suggest that large firms have more guarantees, are more diversified, and thus able to obtain financing at lower costs and present a high level of leverage (Steijvers \& Niskanen, 2013).

Finally, analysis of lag structure of ECM and stock prices indicate that market agents recognize ECM in the current and short-term (one-year) ahead returns, suggesting that excess cash is used to take advantage of investment opportunities. Once again, evidence suggests that firms retain cash based on the speculative motive, and therefore, produce greater current and future (short-term) returns.

\section{REFERENCES}

Acharya, V., Davydenko, S. A., \& Strebulaev, I. A. (2012). Cash holdings and credit risk. The Review of Financial Studies, 25(12), 3572-3609.https://doi.org/10.1093/rfs/hhs106

Arata, N., Sheng, H. H., \& Lora, M. I. (2015). Internationalization and corporate cash holdings: Evidence from Brazil and Mexico. Revista de Administração Contemporânea, 19(SPE), 1-19. http://dx.doi.org/10.1590/ 1982-7849rac20151452

Asem, E., \& Alam, S. (2014). Cash Hoards and Changes in Investors'outlook. Journal of Financial Research, 37(1), 119-137. https://doi.org/10.1111/jfir.12031 
Assaf Neto, A. \& Silva, C. A. T. (2002). Administração do capital de giro (3a ed.). São Paulo: Atlas.

Bates, T. W., Kahle, K. M., \& Stulz, R. M. (2009). Why do US firms hold so much more cash than they used to?. The journal of finance, 64(5), 1985-2021. https://doi.org/10.1111/j.1540-6261.2009.01492.x

Baumol, W. J. (1952). The transactions demand for cash: An inventory theoretic approach. The Quarterly Journal of Economics, 66(4), 545-556. DOI: 10.2307/1882104

Costa, C. M., Paz, L. S., \& Funchal, B. (2008). Are Brazilian Firms Savings Sensitive to Cash Windfalls? Brazilian Business Review, 5(2). DOI: 10.15728/bbr.2008.5.2.4

Dahrouge, F. M., \& Saito, R. (2013). Cash Holdings Policy: A Dynamic Analysis of Brazilian Companies. Brazilian Review of Finance, 11(3), 343-373. https://ideas.repec.org/a/brf/journl/v11y2013i3p343-373.html

Dickinson, V. (2011). Cash flow patterns as a proxy for firm life cycle. The Accounting Review, 86(6), 19691994. https://doi.org/10.2308/accr-10130

Fair, R. C. (1970). The estimation of simultaneous equation models with lagged endogenous variables and first order serially correlated errors. Econometrica: Journal of the Econometric Society, 507-516. DOI: $10.2307 / 1909556$

Forti, C. A. B., Peixoto, F. M., \& Freitas, K. S. (2011). Retenção de caixa, desempenho operacional e valor: um estudo no mercado de capitais brasileiro. Revista de Contabilidade e Organizações, 5(13), 20-33. https://doi.org/10.11606/rco.v5i13.34802

Frezatti, F., \& de Aguiar, A. B. (2007). EBITDA: possíveis impactos sobre o gerenciamento das empresas. Revista Universo Contábil, 3(3), 07-24. http://dx.doi.org/10.4270/ruc.20073

Harford, J., Mansi, S. A., Maxwell, W. F. (2008). Corporate Governance and Firm Cash Holdings in the US. Journal of Financial Economics, 87, 535-555. https://doi.org/10.1016/j.jfineco.2007.04.002

Jensen, M. C. (1986). Agency Costs of Free Cash Flow, Corporate Finance, and Takeovers. American Economic Review, 76(2), 323-329. https://www.jstor.org/stable/1818789

Keynes, J. M. (1936). The General Theory of Employment, Interest and Money.

Kim, C. S., Mauer, D. C., \& Sherman, A. E. (1998). The determinants of corporate liquidity: Theory and evidence. Journal of financial and quantitative analysis, 33(03), 335-359. https://doi.org/10.2307/2331099

Koshio, S. (2005). Nível de Caixa de Empresas Não Financeiras no Brasil: determinantes e Relação com o Endividamento. Tese (Doutorado em Administração) - São Paulo: EAESP/FGV, p. 136. http://hdl.handle. net/10438/2565

Lee, E., \& Powell, R. (2011). Excess cash holdings and shareholder value. Accounting \& Finance, 51(2), 549-574. https://doi.org/10.1111/j.1467-629X.2010.00359.x

Loncan, T. R., \& Caldeira, J. F. (2014). Estrutura de capital, liquidez de caixa e valor da empresa: estudo de empresas brasileiras cotadas em bolsa. Revista Contabilidade \& Finanças - USP, 25(64), 46-59. https://doi. org/10.1590/S1519-70772014000100005

Martins, V. G., Girão, L. F. A. P., \& Gartner, I. R. (2014). Relações Entre o Desempenho Futuro e os Desvios do Caixa-Meta das Empresas Brasileiras. Working Paper In XIV Congresso USP de Controladoria e Contabilidade. Available at: https://congressousp.fipecafi.org/anais/artigos142014/282.pdf

Mikkelson, W. H., \& Partch, M. M. (2003). Do persistent large cash reserves hinder performance?. Journal of Financial and Quantitative Analysis, 38(02), 275-294. https://doi.org/10.2307/4126751

Opler, T., Pinkowitz, L., Stulz, R., \& Williamson, R. (1999). The determinants and implications of corporate cash holdings. Journal of financial economics, 52(1), 3-46. https://doi.org/10.1016/\$0304-405X(99)00003-3

Oler, D.K., \& Picconi, M.P. (2014). Implications of insufficient and excess cash for future performance. Contemporary Accounting Research, 31(1), 253-283. https://doi.org/10.1111/1911-3846.12012

Pimentel, R.C. (2015). Unexpected Earnings, Stock Returns, and Risk in the Brazilian Capital Market. Revista Contabilidade \& Finanças, 26(69), 290-303. http://dx.doi.org/10.1590/1808-057x201501270 
Pimentel, R.C., \& Choudhry, T. (2014). Stock returns under high inflation and interest rates: evidence from the Brazilian market. Emerging Markets Finance and Trade, 50(1), 71-92. https://doi.org/10.2753/ REE1540-496X500104

Simutin, M. (2010). Excess cash and stock returns. Financial Management, 39(3), 1197-1222. https://doi. org/10.1111/j.1755-053X.2010.01109.x

Soares, E. R., \& Galdi, F. C. (2011). Relação dos modelos DuPont com o retorno das ações no mercado brasileiro. Revista Contabilidade \& Finanças, 22(57), 279-298.

https://doi.org/10.1590/S1519-70772011000300004

Steijvers, T., \& Niskanen, M. (2013). The determinants of cash holdings in private family firms. Accounting \& Finance, 53(2), 537-560. https://doi.org/10.1111/j.1467-629X.2012.00467.x

Tortoli, J. P., \& Moraes, M. B. C. (2016). Fatores de Impacto sobre o Saldo de Caixa: Um Estudo em Empresas Brasileiras Não Financeiras de Capital Aberto. Revista Brasileira de Finanças, 14(1), 125-125. https://www. redalyc.org/html/3058/305845303006/

White, H. (1980). A heteroskedasticity-consistent covariance matrix estimator and a direct test for heteroskedasticity. Econometrica, 48 (4), 817-838. https://doi.org/10.2307/2330815

Xu, N., Chen, Q., Xu, Y., \& Chan, K. C. (2016). Political uncertainty and cash holdings: Evidence from China. Journal of Corporate Finance, 40, 276-295. https://doi.org/10.1016/j.jcorpfin.2016.08.007 